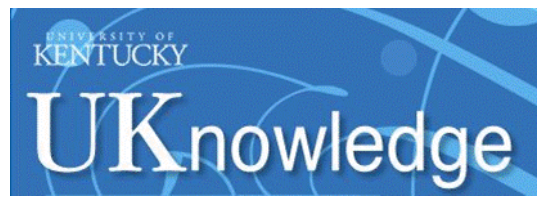

University of Kentucky

UKnowledge

Biosystems and Agricultural Engineering Faculty Publications

Biosystems and Agricultural Engineering

2014

\title{
Pretreatment of Scenedesmus sp. Biomass as a Potential Anaerobic Digestion Substrate
}

Xinyi E

University of Kentucky, xinyi.e@uky.edu

Czarena Crofcheck

University of Kentucky, crofcheck@uky.edu

Follow this and additional works at: https://uknowledge.uky.edu/bae_facpub

Part of the Algae Commons, Biological Engineering Commons, and the Bioresource and Agricultural

Engineering Commons

Right click to open a feedback form in a new tab to let us know how this document benefits you.

\section{Repository Citation}

E, Xinyi and Crofcheck, Czarena, "Pretreatment of Scenedesmus sp. Biomass as a Potential Anaerobic Digestion Substrate" (2014). Biosystems and Agricultural Engineering Faculty Publications. 28. https://uknowledge.uky.edu/bae_facpub/28

This Article is brought to you for free and open access by the Biosystems and Agricultural Engineering at UKnowledge. It has been accepted for inclusion in Biosystems and Agricultural Engineering Faculty Publications by an authorized administrator of UKnowledge. For more information, please contact UKnowledge@lsv.uky.edu. 
Pretreatment of Scenedesmus sp. Biomass as a Potential Anaerobic Digestion Substrate

\author{
Digital Object Identifier (DOI) \\ https://doi.org/10.13031/bet7.10730 \\ Notes/Citation Information \\ Published in Biological Engineering Transactions, v. 7, issue 1, p. 41-52. \\ (C) 2014 ASABE
}

The copyright holder has granted the permission for posting the article here. 


\title{
Pretreatment of Scenedesmus sp. Biomass as a Potential Anaerobic Digestion Substrate
}

\author{
X. E, C. Crofcheck
}

ABSTRACT. Algal biomass can be a potential substrate for anaerobic digestion. However, raw algae cells show a resistance to biological degradation, resulting in a slower methane production rate. Varying thermal and chemical pretreatments of algal biomass were investigated in an attempt to increase soluble organic matter (SOM) yield, which would result in enhanced methane production during subsequent anaerobic digestion. Scenedesmus sp. was harvested using three different procedures: with flocculation, with flocculation and drying, and without flocculation or drying. For all pretreatments and algae types, fluorescence micrographs were obtained to visually confirm the degradation of the algal cell walls. A complete $2 \times 3 \times 4$ factorial design was applied for the algal biomass pretreatment study, including two heating temperatures $\left(50^{\circ} \mathrm{C}\right.$ or $\left.90^{\circ} \mathrm{C}\right)$, three heating durations $(10,30$, or $60 \mathrm{~min})$, and four $\mathrm{NaOH}$ concentrations $(0 \%, 3 \%, 6 \%$, or $12 \% \mathrm{~g}$ $\mathrm{NaOH} \mathrm{g}^{-1} \mathrm{DW}$ of algae). For algae cells with no flocculant addition, SOM yield increased by $15 \%$ with a moderate pretreatment of heating at $50^{\circ} \mathrm{C}$ in $3 \% \mathrm{NaOH}$ for 60 min. For dried algae, the baseline SOM yield was higher than in the other algae, such that there was only a noticeable increase with the more severe pretreatments. For flocculated algae, the most severe pretreatment increased SOM yield by $17.2 \%$, but overall the SOM increase was less than with fresh algae. Flocculation appears to inhibit cell wall disruption, but thermal chemical treatment can hydrolyze some flocculant polymers, which eases the flocculation and facilitates cell destruction.

Keywords. Algae, Pretreatment, Scenedesmus.

A naerobic digestion has been studied for decades as a practical approach to decompose microalgae biomass and produce methane for use as fuel (Golueke et al., 1957; Foree and McCarty, 1970; Chen, 1987; Ras et al., 2011). In fact, anaerobic decomposition of microalgae takes place in natural aquatic systems. Because of gravitational sedimentation, microalgae eventually sink to the anoxic and aphotic zones and are broken down by anaerobic bacteria (Foree and McCarty, 1970). If this anaerobic digestion takes place in a bioreactor, microalgae can be degraded into inorganic elements, which can be transferred back to a photobioreactor and support large-scale microalgae growth. Thus, there is a strong motivation to investigate the potential of algal biomass as an anaerobic digestion substrate and explore the possibility of improving the digestion efficiency.

\footnotetext{
Submitted for review in April 2014 as manuscript number BET 10730; approved for publication by the Biological Engineering Division of ASABE in May 2014.

The information reported in this article is part of a project of the Kentucky Agricultural Experiment Station and is published with the approval of the Director.

The authors are Xinyi E, Graduate Student, and Czarena Crofcheck, ASABE Member, Associate Professor Department of Biosystems and Agricultural Engineering, University of Kentucky, Lexington, Kentucky. Corresponding author: Czarena Crofcheck, 212 CE Barnhart, University of Kentucky, Lexington, KY 40546; phone: 859-218-4349; email: crofcheck@uky.edu.
} 
Anaerobic digestion is potentially suitable for Scenedesmus sp. degradation; however, intact algal cells are reported to resist bacterial attack due to their rigid cell wall structure (Chen, 1987). Golueke et al. (1957) compared the degradation rates of raw sewage and microalgae and showed that $60 \%$ of raw sewage was degraded after $35^{\circ} \mathrm{C}$ mesophilic digestion, but only $40 \%$ of microalgae were degraded. Chen (1987) studied anaerobic digestion of microalgae collected from the effluent of high-rate sewage stabilization ponds. Prior to thermal pretreatment, the methane production was $0.14 \mathrm{~L} \mathrm{gVS}^{-1}$. Methane production increased to $0.20 \mathrm{~L} \mathrm{gVS}^{-1}$ when the substrate microalgae were heated to $50^{\circ} \mathrm{C}$ for $30 \mathrm{~min}$. To improve cell degradation and methane production, pretreatment should be carried out prior to anaerobic digestion. Cell wall disruption can be executed by thermal, chemical, enzymatic, or mechanical pretreatment (Gonzalez-Fernandez et al., 2011).

Thermal pretreatment is one of the most discussed methods (Chen, 1987; MendesPinto et al., 2001; Barjenbruch and Kopplow, 2003; Appels et al., 2010; GonzalezFernandez et al., 2011; Miranda et al., 2012). Chen (1987) studied the effects of thermal pretreatment on methane production efficiency using microalgae collected from the effluent of high-rate sewage stabilization ponds. When the heating duration was $30 \mathrm{~min}$, hightemperature pretreatment appeared to significantly improve methane production, with the highest yield $\left(0.25 \mathrm{~L} \mathrm{gVS}^{-1}\right)$ achieved with microalgae subjected to $100^{\circ} \mathrm{C}$ or $120^{\circ} \mathrm{C}$ pretreatment. Moderate temperature $\left(40^{\circ} \mathrm{C}\right)$ also improved the methane yield but showed less increase $\left(0.17\right.$ vs. control $\left.0.14 \mathrm{~L} \mathrm{gVS}^{-1}\right)$. The heating duration at $100^{\circ} \mathrm{C}$ was also studied. Comparing $15 \mathrm{~min}$ to $4 \mathrm{~h}$, the latter duration resulted in $0.04 \mathrm{~L} \mathrm{gVS}^{-1}$ more methane produced. In addition to temperature and duration, the effects of substrate concentration were tested. Interestingly, increasing the concentration from $3.7 \%$ to $22.5 \%$ made the methane yield plunge by $18 \%$.

Another study carried out by Gonzalez-Fernandez et al. (2012) revealed the effects of temperature $\left(70^{\circ} \mathrm{C}\right.$ vs. $\left.90^{\circ} \mathrm{C}\right)$ on the soluble chemical oxygen demand (COD) of the substrate and the methane yield. After 180 min of heating, soluble CODs of Scenedesmus sludge were increased 4 or 5 fold with $70^{\circ} \mathrm{C}$ or $90^{\circ} \mathrm{C}$, respectively. The methane production over 33 days showed that raw microalgae and $70^{\circ} \mathrm{C}$ treated microalgae resulted in similar amounts of methane, but $90^{\circ} \mathrm{C}$ treated microalgae produced two times more biogas. For the first 10 days, pretreated microalgae showed significantly higher methane yield rates than raw microalgae, especially when heated at $90^{\circ} \mathrm{C}$.

Appels et al. (2010) studied the pretreatment of wastewater sludge and demonstrated a similar trend but with more significant differences. Pretreatments at $80^{\circ} \mathrm{C}$ and $70^{\circ} \mathrm{C}$ rendered the same amount of methane when the heating duration was 15 min. Pretreatment at $80^{\circ} \mathrm{C}$ showed slightly higher biogas yield when the duration was prolonged to $60 \mathrm{~min}$. By contrast, pretreatment at $90^{\circ} \mathrm{C}$ gave superior results at all three heating duration (15, 30 , and $60 \mathrm{~min})$. Thermal pretreatment was often accompanied by high pressure if the process was implemented in an autoclave (Mendes-Pinto et al., 2001; Barjenbruch and Kopplow, 2003; Miranda et al., 2012). Barjenbruch and Kopplow (2003) investigated the thermal pretreatment of sewage sludge by autoclave at three temperatures $\left(80^{\circ} \mathrm{C}, 90^{\circ} \mathrm{C}\right.$, and $121^{\circ} \mathrm{C}$ ) and found that $90^{\circ} \mathrm{C}$ produced the greatest improvement.

Alkalines or acids have also been incorporated into the thermal pretreatment of microalgae to disrupt cell walls (Chen, 1987; Mendes-Pinto et al., 2001; Halim et al., 2012; Miranda et al., 2012). Chen (1987) heated microalgae sludge at $100^{\circ} \mathrm{C}$ for $8 \mathrm{~h}$ with various $\mathrm{NaOH}$ concentrations. Interestingly, the $\mathrm{NaOH}$-free treatment gave the highest methane yield, and increasing $\mathrm{NaOH}$ from $2 \%$ to $20 \%$ caused the methane yield to plunge to almost zero, even though the samples were neutralized to $\mathrm{pH} 7$ after all pretreatments. 
Sulfuric acid solution was also studied to aid cell wall disruption (Halim et al., 2012). The most severe cell wall disruption took place when Chlorococcum sp. was subjected to $8 \%$ sulfuric acid and heated to $160^{\circ} \mathrm{C}$ for $45 \mathrm{~min}$. Chemical pretreatment can potentially break down the recovery product as well. Haematococcus pluvialis, which is an important natural source of carotenoid astaxanthin for the aquaculture industry, was subjected to several pretreatments to improve the carotenoid recovery efficiency (Mendes-Pinto et al., 2001). Both acidic and alkaline pretreatments resulted in a significant loss of carotenoid compared to the control. By contrast, mechanical disruption and autoclave pretreatment led to minimal loss of carotenoid and higher product recovery.

Mechanical disruption and ultrasonication have also been proposed to facilitate cell wall disruption (Barjenbruch and Kopplow, 2003; Mendes-Pinto et al., 2001; Halim et al., 2012). Scanning electron micrographs of Haematococcus pluvialis (Mendes-Pinto et al., 2001) showed that both homogenization and autoclaving can effectively fragment cell walls. Spray-drying only slightly decreased the size of the cells without impairing the cell wall, which supported the results from another study comparing the biogas yield of fresh vs. dried microalgae (Mussgnug et al., 2010). In another study, Miranda et al. (2012) compared the effects of thermal, chemical-thermal, sonication, bead-beating, and homogenization pretreatments on sugar extraction from Scenedesmus obliquus cells. The results showed that acidic-thermal pretreatment had superior effects on sugar extraction, and alkaline-thermal pretreatment along with all three mechanical approaches were less effective. Acid pretreatment can be beneficial for microalgal bioethanol production. However, for biogas production, alkaline pretreatment should be more appropriate since the fermentation $\mathrm{pH}$ is more basic (Chen, 1987).

In this study, varying thermal and chemical pretreatments of algal biomass were investigated in an attempt to increase the soluble organic matter (SOM) yield, which would result in enhanced methane production during subsequent anaerobic digestion. Scenedesmus sp. was harvested using three different processes: with flocculation, with flocculation and drying, and without flocculation or drying. The success of algal pretreatment was evaluated based on cell wall disruption as determined by (1) microscopic fluorescence observations and (2) the release of SOM. The optimum pretreatment based on these criteria would likely result in the highest methane production during subsequent anaerobic digestion.

\section{Materials and Methods}

\section{Algae Pretreatment}

Scenedesmus sp. was cultivated in $3800 \mathrm{~L}$ tubular photobioreactors (PBRs) and $500 \mathrm{~mL}$ glass flasks. The two cultivation setups used similar media and the same $\mathrm{CO}_{2}$ level (3\%) but different light sources: sunlight for the PBRs and artificial fluorescent light for the flasks. The medium for the small-scale cultivation was composed of $\left(\mathrm{g} \mathrm{L}^{-1}\right)$ : $0.137 \mathrm{CO}\left(\mathrm{NH}_{2}\right)_{2}, 0.118 \mathrm{KH}_{2} \mathrm{PO}_{4}, 0.109 \mathrm{MgSO}_{4} \cdot 7 \mathrm{H}_{2} \mathrm{O}, 0.055 \mathrm{CaCl}_{2} \cdot 2 \mathrm{H}_{2} \mathrm{O}$, and 0.02 $\mathrm{Na} \cdot$ EDTA $\cdot \mathrm{Fe}$. Considering the significant size $(3800 \mathrm{~L})$ of the PBRs, commercial fertilizers (triple super phosphate and potash) replaced $\mathrm{KH}_{2} \mathrm{PO}_{4}$, and $\mathrm{Mg}^{2-}$ was supplied by tap water. Nevertheless the nutrients' elemental levels were kept consistent between the media of the flasks and PBRs. Both media were prepared with tap water. Algae harvested from the PBRs underwent one of two dewatering procedures prior to storage: (1) flocculating or (2) flocculating, filtering, and oven-drying. Cationic polyacrylamide (5 to 
$10 \mathrm{ppm}$ ) was applied to aid the flocculation of algae (the algae were allowed to settle to the bottom, and the algae-free media was discarded), and the algal biomass was concentrated from 1 to $25 \mathrm{~g} \mathrm{~L}^{-1}$. For the dried algae, flocculated algae were filtered, and the resulting filter cakes were dried at $60^{\circ} \mathrm{C}$ until the moisture content was reduced to less than $5 \%$. Algae harvested from flasks was dewatered by moderate centrifugation (3000 rpm for $20 \mathrm{~min}$ ) and reconstituted into $10 \mathrm{~g} \mathrm{~L}^{-1}$ algal stock by adding previously boiled, roomtemperature tap water. The other two types of algae biomass were also reconstituted into $10 \mathrm{~g} \mathrm{~L}^{-1}$ algal stock. For convenience, the samples were denoted as flocculated algae, dried algae, and fresh algae. Fresh algae were strictly from the small-scale cultivation.

A complete $2 \times 3 \times 4$ factorial design was applied for the algal biomass pretreatment study, including two heating temperatures $\left(50^{\circ} \mathrm{C}\right.$ or $\left.90^{\circ} \mathrm{C}\right)$, three heating durations $(10$, 30 , or $60 \mathrm{~min}$ ), and four $\mathrm{NaOH}$ concentrations $\left(0 \%, 3 \%, 6 \%\right.$, or $12 \% \mathrm{~g} \mathrm{NaOH} \mathrm{g}^{-1} \mathrm{DW}$ of algae) in $10 \mathrm{~mL}$ of the $10 \mathrm{~g} \mathrm{DW}$ algae $\mathrm{L}^{-1}$ algae stock solutions. Temperatures and durations were based on the study by Gonzalez-Fernandez et al. (2012), and $\mathrm{NaOH}$ dosages were based on the study by Chen (1987).

Chemical oxygen demand (COD) was used to determine the release of SOM after cell wall destruction due to pretreatment (Gonzalez-Fernandez et al., 2012). Soluble COD (SCOD) and total COD (TCOD) were measured for each sample, and the increase in the percentage of SCOD/TCOD due to treatment was compared. The treated samples $(0.5 \mathrm{~mL})$ were diluted with deionized (DI) water $(2 \mathrm{~mL})$ and centrifuged at $4000 \mathrm{rpm}$ for $8 \mathrm{~min}$. Supernatants were pipetted into $5 \mathrm{~mL}$ centrifuge vials, and $2.5 \mathrm{~mL}$ DI water was mixed with the pellet to undergo another centrifugation. Supernatants from the second centrifugation were pipetted and combined with the supernatants from the first centrifugation. The combined supernatants were centrifuged again to remove any residual debris. The dilution factor for SCOD was 10. TCOD samples were diluted 20 times with DI water before the test. COD tests were conducted in prepacked tubes (Hach Co., Loveland, Colo.). Each tube contained a $2 \mathrm{~mL}$ sample that was digested at $150^{\circ} \mathrm{C}$ for $2 \mathrm{~h}$. After cooling to room temperature, the absorbance of the tube was read at $620 \mathrm{~nm}$ using a spectrophotometer. The standards were serial dilutions of potassium dichromate solutions (25, $50,100,200,400,600,800,1000,1289$, and $1475 \mathrm{ppm})$. The SCOD and TCOD of each sample were calculated from the calibration curve. The increase of SOM in the algae slurry was determined as the difference between the percentage of SCOD/TCOD of the raw and treated samples.

\section{Dual-Fluorescence Microscopy}

The raw or pretreated Scenedesmus sp. was centrifuged, and the pellets were kept frozen at $-20^{\circ} \mathrm{C}$ for less than one month before fluorescent labeling. Sytox Green nucleic acid stain (Molecular Probes, Inc., Eugene, Ore.) was used to label cells with compromised cell walls and cell membranes (Sato et al., 2004). The stain was diluted 100 times with DI water prior to use, and the final concentration was $50 \mu \mathrm{M}$. The algae pellets were suspended in the media, and $1 \mu \mathrm{L}$ of the algae culture was mixed with $1 \mu \mathrm{L}$ of the diluted stain on the microscope slides. The samples were incubated in the dark for $5 \mathrm{~min}$. A fluorescence microscope (Eclipse E600, Nikon, Japan) was used, and images were taken with a digital camera (Coolpix 5000, Nikon, Japan). The chlorophylls were autofluorescent pigments excited by 540-580 nm light and emitted bright red. The Sytox Green was excited by $465-495 \mathrm{~nm}$ light and emitted bright green. The light source was a mercury lamp (C-SHG1, Nikon, Japan). 


\section{Statistical Analysis}

All pairwise comparisons were conducted according to Tukey's honest significant differences method with $\alpha=0.05$. ANOVA was performed for each type of algae before the pairwise comparisons. SAS 9.3 (SAS Institute, Inc., Cary, N.C.) was used to perform the statistical tests.

\section{Results and Discussion}

Three types of algae biomass (fresh algae with no flocculation or drying, flocculated algae with flocculation, and dried algae with both flocculation and drying) were collected and treated using the 24 pretreatment combinations. SOM of the sample was expressed as the percentage of SCOD/TCOD, shown for the raw and treated samples in table 1 . ANOVA showed that temperature had a significant effect $(\mathrm{p}<0.02)$, while duration was not significant for all three algae types. The effect of $\mathrm{NaOH}$ dosage was not significant for fresh algae but was significant for flocculated and dried algae $(\mathrm{p}<0.001)$. It was decided to analyze each algae type using a pairwise comparison.

For fresh algae, SOM yield increased $6 \%$ to $15 \%$ after thermal chemical treatments. High temperature $\left(90^{\circ} \mathrm{C}\right)$ did not increase the amount of SOM compared to the mesophilic temperature $\left(50^{\circ} \mathrm{C}\right)$. The maximum SOM increase after $50^{\circ} \mathrm{C}$ or $90^{\circ} \mathrm{C}$ heating was $14.8 \%$ or $15.5 \%$, respectively. Gonzalez-Fernandez et al. (2012) showed that two heating temperatures $\left(70^{\circ} \mathrm{C}\right.$ or $\left.90^{\circ} \mathrm{C}\right)$ had similar effects on the soluble COD yield when the heating duration was less than $50 \mathrm{~min}$.

Table 1. Increase of soluble organic matter (SOM) in fresh, flocculated, and oven-dried algae samples after pretreatment. The increase of SOM is presented as the absolute increase of SCOD/TCOD between raw and treated samples $(n=3) .^{[\text {a] }}$

\begin{tabular}{|c|c|c|c|c|c|c|c|c|c|c|c|}
\hline \multirow{2}{*}{$\begin{array}{c}\text { Temp. } \\
\left({ }^{\circ} \mathrm{C}\right)\end{array}$} & \multirow{2}{*}{$\begin{array}{c}\mathrm{NaOH} \\
(\%)\end{array}$} & \multirow{2}{*}{$\begin{array}{l}\text { Time } \\
(\mathrm{min})\end{array}$} & \multicolumn{3}{|c|}{ Fresh Algae (\%) } & \multicolumn{3}{|c|}{ Flocculated Algae (\%) } & \multicolumn{3}{|c|}{ Dried Algae (\%) } \\
\hline & & & Raw & Treated & Increase & Raw & Treated & Increase & Raw & Treated & Increase \\
\hline \multirow{12}{*}{50} & \multirow{3}{*}{0} & 10 & \multirow{6}{*}{3.4} & 15.4 & $12.0 \mathrm{~b}$ & \multirow{6}{*}{10.3} & 17.9 & $7.6 \mathrm{a}$ & \multirow{6}{*}{7.5} & 7.3 & $-0.2 \mathrm{a}$ \\
\hline & & 30 & & 16.1 & $12.7 \mathrm{~b}$ & & 19 & $8.7 \mathrm{ab}$ & & 7.1 & $-0.4 \mathrm{a}$ \\
\hline & & 60 & & 15.2 & $11.8 \mathrm{~b}$ & & 17.3 & $7.0 \mathrm{a}$ & & 7.5 & $0.0 \mathrm{a}$ \\
\hline & \multirow{3}{*}{3} & 10 & & 16.4 & $13.0 \mathrm{c}$ & & 20.9 & $10.6 \mathrm{~b}$ & & 7.1 & $-0.4 \mathrm{a}$ \\
\hline & & 30 & & 17.7 & $14.3 \mathrm{~cd}$ & & 19.8 & $9.5 \mathrm{~b}$ & & 8.6 & $1.1 \mathrm{ab}$ \\
\hline & & 60 & & 18.2 & $14.8 \mathrm{~cd}$ & & 20 & $9.7 \mathrm{~b}$ & & 8.6 & $1.1 \mathrm{ab}$ \\
\hline & \multirow{3}{*}{6} & 10 & \multirow{6}{*}{1.7} & 13.2 & $11.5 \mathrm{~b}$ & \multirow{6}{*}{2.7} & 11.9 & $9.2 \mathrm{~b}$ & \multirow{6}{*}{7.4} & 10.4 & $3.0 \mathrm{~b}$ \\
\hline & & 30 & & 13.2 & $11.5 \mathrm{~b}$ & & 10.5 & $7.8 \mathrm{a}$ & & 9.9 & $2.5 \mathrm{ab}$ \\
\hline & & 60 & & 10.4 & $8.7 \mathrm{ab}$ & & 9.8 & $7.1 \mathrm{a}$ & & 9.2 & $1.8 \mathrm{ab}$ \\
\hline & \multirow{3}{*}{12} & 10 & & 9.1 & $7.4 \mathrm{ab}$ & & 11 & $8.3 \mathrm{ab}$ & & 11.7 & $4.3 \mathrm{c}$ \\
\hline & & 30 & & 9.6 & $7.9 \mathrm{ab}$ & & 11.4 & $8.7 \mathrm{ab}$ & & 10.4 & $3.0 \mathrm{~b}$ \\
\hline & & 60 & & 9.8 & $8.1 \mathrm{ab}$ & & 10.6 & $7.9 \mathrm{a}$ & & 11.2 & $3.8 \mathrm{c}$ \\
\hline \multirow{12}{*}{90} & \multirow{3}{*}{0} & 10 & \multirow{6}{*}{3.4} & 9.6 & $6.2 \mathrm{a}$ & \multirow{6}{*}{10.3} & 17.2 & $6.9 \mathrm{a}$ & & 6.5 & $-1.0 \mathrm{a}$ \\
\hline & & 30 & & 10.2 & $6.8 \mathrm{a}$ & & 17.7 & $7.4 \mathrm{a}$ & & 6.8 & $-0.7 \mathrm{a}$ \\
\hline & & 60 & & 10.3 & $6.9 \mathrm{a}$ & & 17.5 & $7.2 \mathrm{a}$ & 75 & 6.4 & $-1.1 \mathrm{a}$ \\
\hline & \multirow{3}{*}{3} & 10 & & 11.5 & $8.1 \mathrm{ab}$ & & 19.4 & $9.1 \mathrm{ab}$ & 1.5 & 7.5 & $0.0 \mathrm{a}$ \\
\hline & & 30 & & 10.2 & $6.8 \mathrm{ab}$ & & 20.1 & $9.8 \mathrm{~b}$ & & 7.6 & $0.1 \mathrm{a}$ \\
\hline & & 60 & & 11 & $7.6 \mathrm{ab}$ & & 21.1 & $10.8 \mathrm{~b}$ & & 9.8 & $2.3 \mathrm{ab}$ \\
\hline & \multirow{3}{*}{6} & 10 & \multirow{6}{*}{1.7} & 10.6 & $8.9 \mathrm{ab}$ & \multirow{6}{*}{2.7} & 8.9 & $6.2 \mathrm{a}$ & & 10.7 & $3.3 \mathrm{~b}$ \\
\hline & & 30 & & 10.7 & $9.0 \mathrm{ab}$ & & 10 & $7.3 \mathrm{a}$ & & 13.4 & $6.0 \mathrm{~cd}$ \\
\hline & & 60 & & 12.3 & $10.6 \mathrm{~b}$ & & 11.3 & $8.6 \mathrm{ab}$ & 74 & 13 & $5.6 \mathrm{~cd}$ \\
\hline & \multirow{3}{*}{12} & 10 & & 14.8 & $13.1 \mathrm{c}$ & & 15 & $12.3 \mathrm{c}$ & 1.4 & 16.3 & $8.9 \mathrm{~d}$ \\
\hline & & 30 & & 15.5 & $13.8 \mathrm{c}$ & & 16.7 & $14.0 \mathrm{~d}$ & & 17.8 & $10.4 \mathrm{~d}$ \\
\hline & & 60 & & 17.2 & $15.5 \mathrm{~cd}$ & & 19.9 & $17.2 \mathrm{e}$ & & 18.9 & $11.5 \mathrm{de}$ \\
\hline
\end{tabular}

[a] Within the same algae type, means followed by the same letter are not significantly different at $\alpha=0.05$. 
The effect of alkali $(\mathrm{NaOH})$ addition was significant (table $1, \mathrm{p}<0.0001)$. The average $\mathrm{pH}$ values of algae slurries with various amounts of $\mathrm{NaOH}(0 \%, 3 \%, 6 \%$, or $12 \% \mathrm{~g}$ $\mathrm{NaOH}$ of g DW algae) were $6.5,7.0,9.5$, and 11.0 , respectively. When heating at $50^{\circ} \mathrm{C}$ for the same period of time, increasing the alkali concentration inhibited the release of $\mathrm{SOM}$ from the algal cells. When heating at $90^{\circ} \mathrm{C}$ for the same amount of time, increasing $\mathrm{NaOH}$ concentrations apparently accelerated the release of SOM from the cells. Chen (1987) studied the alkali thermal treatment on algae collected from the effluent of highrate sewage stabilization ponds. He found that as the dosage of $\mathrm{NaOH}$ increased from $3 \%$ to $12 \%$ of DW algae, the methane specific gas production (SGP) of the algae decreased from $0.24 \mathrm{~L} \mathrm{gVS}^{-1}$ to nearly zero when the heating temperature was $100^{\circ} \mathrm{C}$. He also found that $\mathrm{NaOH}$-free treatment rendered the highest gas production rate. In the current study, the pretreatment index is SOM (expressed as SCOD/TCOD) instead of SGP. But the soluble COD of algae biomass showed a positive relation to SGP (Ras et al., 2011; Gonzalez-Fernandez et al., 2012). Current results showed that higher $\mathrm{NaOH}$ dosage aided the release of organic matter from algal cells at $90^{\circ} \mathrm{C}$ but not at $50^{\circ} \mathrm{C}$. The heating duration did not play a significant role in cell wall destruction. In fact, Chen (1987) demonstrated that heating durations longer than $20 \mathrm{~h}$ drastically inhibited gas production.

Under a fluorescence microscope, cells stained with Sytox Green with de-activated chlorophyll pigments appear dim red, while cells containing intact chlorophyll pigments appear intense red. The green light intensity is related to the amount of dye penetrating the cells and indicates the severity of cell wall destruction. For fresh algae, the alkali solution provided protection to the chlorophyll pigments after heating at $90^{\circ} \mathrm{C}$, since red fluorescence was observed (fig. 1n). However, alkali treatment did not provide protection to the cell walls but instead facilitated cell wall disruption (fig. 11 and 1o). Visually, it appeared that heating at $90^{\circ} \mathrm{C}$ caused more severe cell wall destruction compared to heating at $50^{\circ} \mathrm{C}$, even though the $90^{\circ} \mathrm{C}$ treatment failed to significantly increase $\mathrm{SOM}$ yield over the $50^{\circ} \mathrm{C}$ treatment. The cell matrix is made of proteins, carbohydrates, and lipids, which dynamically interact and bond with each other. When the cell walls and membranes are disrupted, this organic matter does not completely dissolve and disperse into the extracellular space. Partially destroying the cell walls causes some organic matter to leach from the cells but does not guarantee they are in a soluble form (SOM). Therefore, when maximum cell wall destruction was observed under the fluorescence microscope, a corresponding increase of SOM was not always observed.

In the case of cation polyacrylamide (CPAM) flocculated fresh algae, the combination of high temperature $\left(90^{\circ} \mathrm{C}\right)$ and a high dose of $\mathrm{NaOH}(12 \%$ of DW algae) resulted in a significant increase in SOM, ranging from $12.3 \%$ to $17.2 \%$. Interestingly, heating at $90^{\circ} \mathrm{C}$ with $6 \% \mathrm{NaOH}$ produced the smallest increase in SOM $(6 \%)$ among all treatments. The $\mathrm{NaOH}$ concentration significantly impacted SOM yield at $90^{\circ} \mathrm{C}$ but not at $50^{\circ} \mathrm{C}$ (table 1). The $\mathrm{pH}$ manipulation had no significant effect between samples treated at the two temperature levels. Microscope images showed that algae cells started to aggregate as treatment conditions intensified (fig. 2).

After heating at $50^{\circ} \mathrm{C}$ without addition of alkali, cells appeared as individuals, and slight cell wall destruction occurred (fig. 2). As $12 \% \mathrm{NaOH}$ was added to the slurry, cells clumped and formed flakes. Meanwhile, more cell walls were disrupted (comparing fig. $2 \mathrm{f}$ to fig. $2 \mathrm{i}$ ). At $90^{\circ} \mathrm{C}$, even without addition of alkali, cells coagulated, along with considerable cell wall destruction (fig. 21). Based on the fluorescence images, no signifi- 


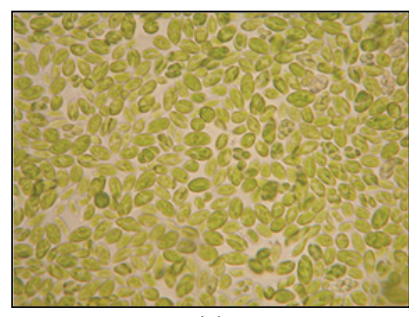

(a)

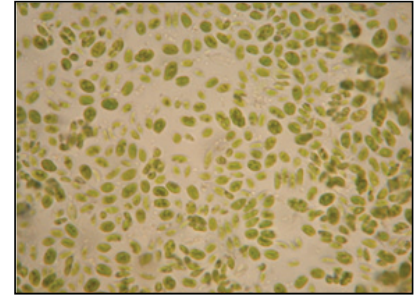

(d)

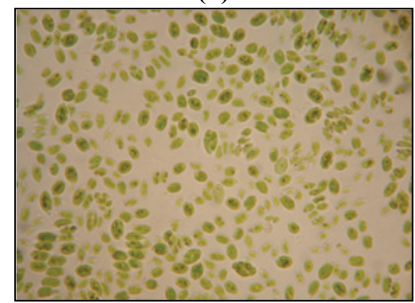

(g)

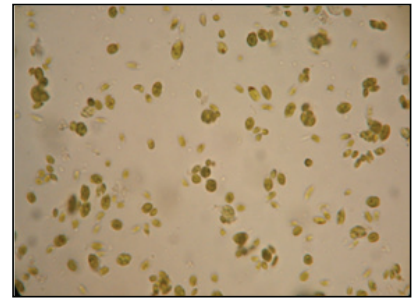

(j)

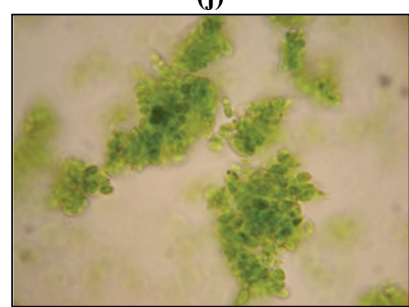

(m)

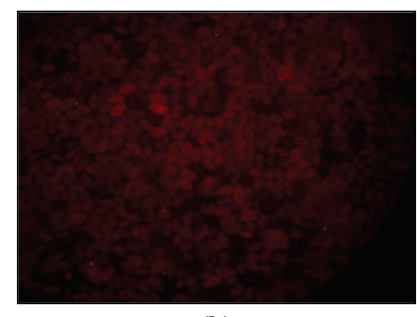

(b)

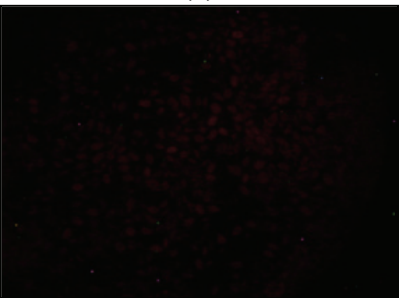

(e)

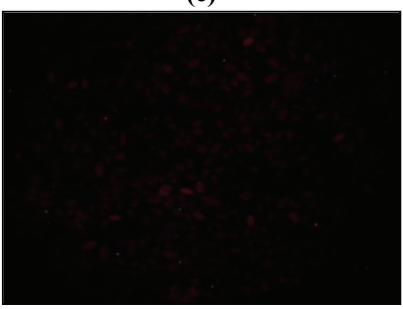

(h)

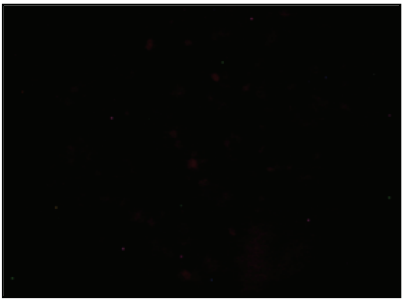

(k)

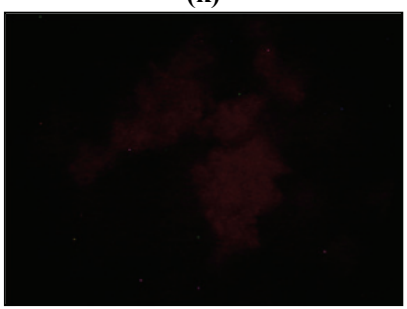

(n)

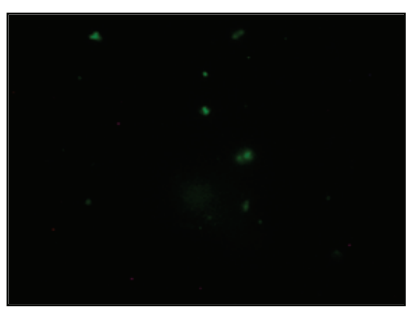

(c)

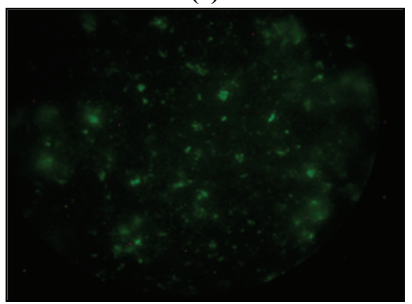

(f)

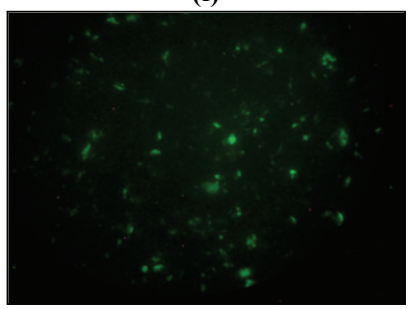

(i)

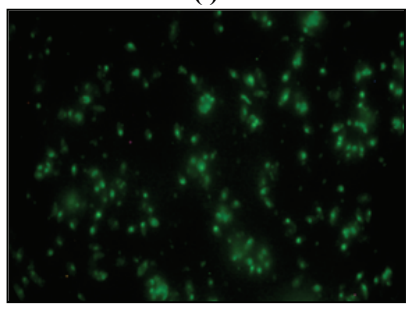

(l)

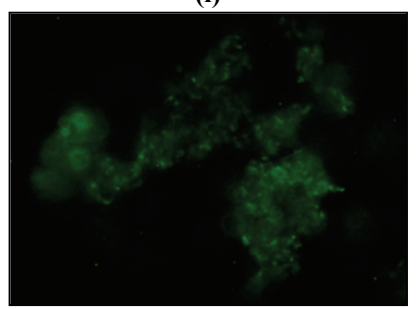

(o)

Figure 1. Microscopy images of fresh algae: (left to right) light microscopy, red fluorescence microscopy representing live cells, and green fluorescence microscopy representing dead cells, (a-c) raw fresh algae, (d-f) fresh algae treated with $0 \% \mathrm{NaOH}$ at $50^{\circ} \mathrm{C}$ for $10 \mathrm{~min}$, (g-i) fresh algae treated with $12 \% \mathrm{NaOH}$ at $50^{\circ} \mathrm{C}$ for $10 \mathrm{~min},(\mathrm{j}-\mathrm{l})$ fresh algae treated with $0 \% \mathrm{NaOH}$ at $90^{\circ} \mathrm{C}$ for $10 \mathrm{~min}$, and $(\mathrm{m}-\mathrm{o})$ fresh algae treated with $12 \% \mathrm{NaOH}$ at $90^{\circ} \mathrm{C}$ for $10 \mathrm{~min}$. 


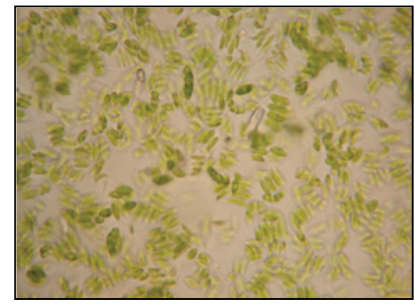

(a)

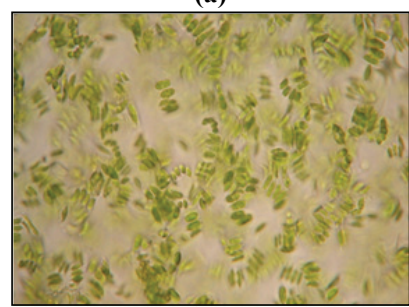

(d)

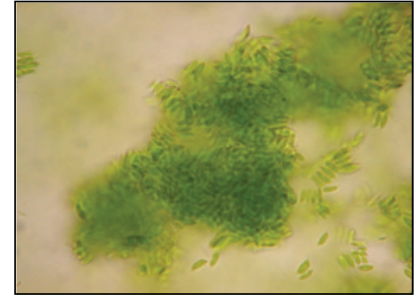

(g)

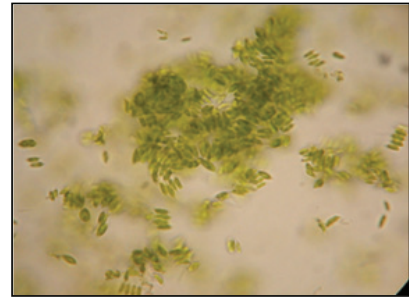

(j)

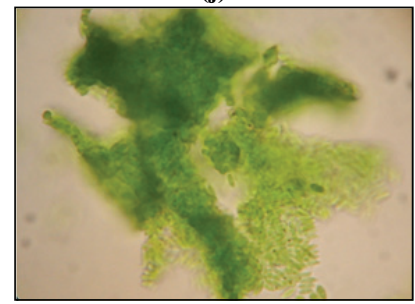

(m)

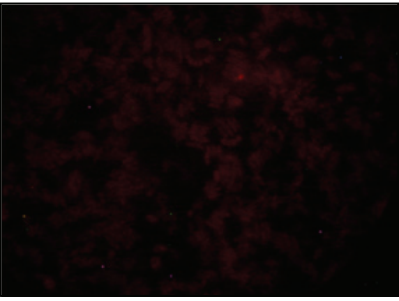

(b)

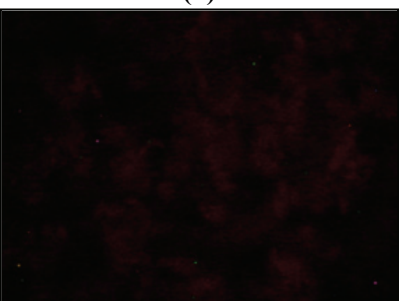

(e)

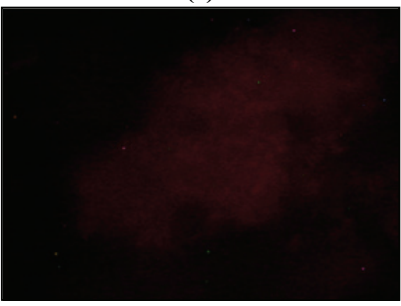

(h)

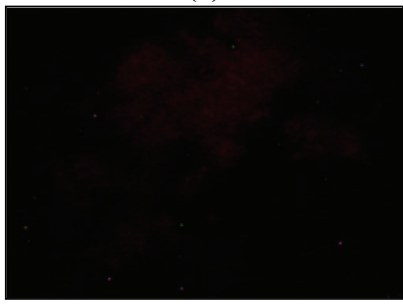

(k)

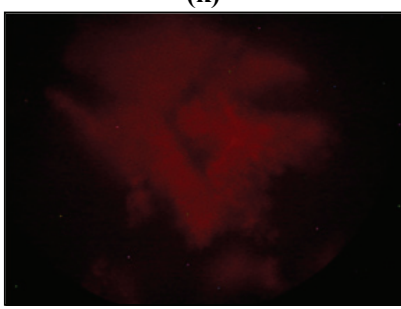

(n)

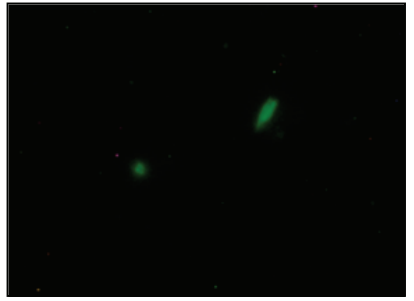

(c)

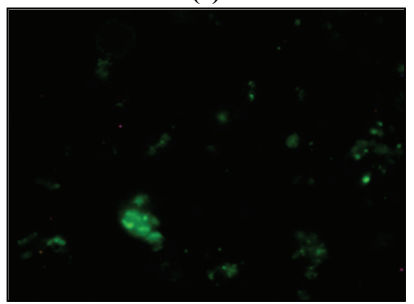

(f)

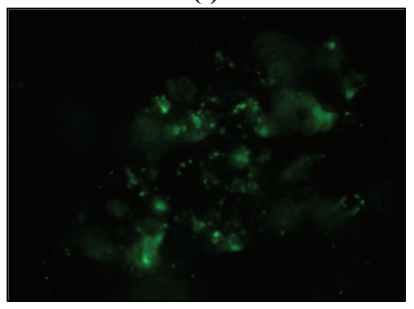

(i)

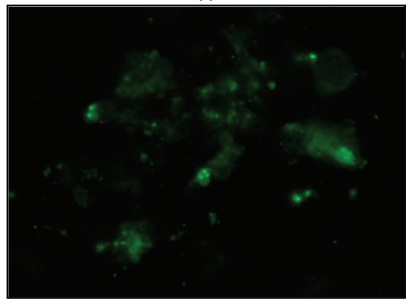

(I)

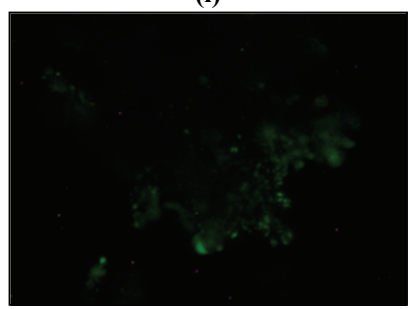

(o)

Figure 2. Microscopy images of flocculated algae: (left to right) light microscopy, red fluorescence microscopy representing live cells, and green fluorescence microscopy representing dead cells, (a-c) raw flocculated algae, (d-f) flocculated algae treated with $0 \% \mathrm{NaOH}$ at $50^{\circ} \mathrm{C}$ for $10 \mathrm{~min}$, (g-i) flocculated algae treated with $12 \% \mathrm{NaOH}$ at $50^{\circ} \mathrm{C}$ for $10 \mathrm{~min}$, (j-l) flocculated algae treated with $0 \% \mathrm{NaOH}$ at $90^{\circ} \mathrm{C}$ for $10 \mathrm{~min}$, and (m-o) flocculated algae treated with $12 \% \mathrm{NaOH}$ at $90^{\circ} \mathrm{C}$ for $10 \mathrm{~min}$. 
cant difference in terms of cell wall disruption was observed between alkali-treated algae and non-alkali-treated algae (comparing fig. 21 to fig. 2o).

The way SOM reacted to alkali and heating in the flocculated algae samples showed a different pattern compared to the fresh algae samples (table 1). At $50^{\circ} \mathrm{C}$, the SOM increases in the flocculated algae samples were slightly less than those for fresh algae. At $90^{\circ} \mathrm{C}$, as the dosage of $\mathrm{NaOH}$ increased, both algae samples had a similar SOM increase. Flocculants should play a role in how algal cells react to the altered extracellular $\mathrm{pH}$ and temperature. The flocculant polymers are water-soluble and can adsorb onto the algae cell surface by electrostatic interaction, hydrogen bonds, or ionic bonds (Bolto and Gregory, 2007). Once the equilibrium of the adsorption is attained, three distinct segments are formed: trains where portions of the polymer are attached to the surface, tails where portions of polymer are projected into the solution, and loops where a portion of polymer is between two trains (Bolto and Gregory, 2007). When the $\mathrm{pH}$ is above 8.5, degradation can occur to CPAM, and flocculation is inhibited as a result (Bolto and Gregory, 2007). Heating at $50{ }^{\circ} \mathrm{C}$ without alkali increased the $\mathrm{SOM}$ of fresh algae and flocculated algae by $12 \%$ and $8 \%$ (table 1), respectively. It seemed that flocculation of algae cells inhibited cell wall disruption. When heated at $90^{\circ} \mathrm{C}$ with alkali addition, CPAM degradation took place and flocculation was inhibited. Under these conditions, cell wall disruption happened at a similar intensity for both algae samples.

The $\mathrm{pH}$ of the dried algae samples with $\mathrm{NaOH}$ addition was in a range (9 to 12) similar to that of the fresh and flocculated algae samples, but pretreatment appeared to have less effect on increasing extracellular SOM in the dried algae (table 1). It is worth noting that the initial SOM of dried algae $(7.4 \%$ and $7.5 \%)$ prior to pretreatment was consistent and higher than that of fresh algae (1.7\% and 3.4\%). This was because drying altered the cell structure and disrupted cell wall continuity (Mendes-Pinto et al., 2001). Heating $\left(50^{\circ} \mathrm{C}\right.$ or $\left.90^{\circ} \mathrm{C}\right)$ without $\mathrm{NaOH}$ had no effect on improving the release of SOM from the cell matrix (table 1). Addition of $\mathrm{NaOH}$ led to the release of additional SOM; however, increasing the dosage at $50^{\circ} \mathrm{C}$ had no significant effect $(p=0.2184)$ on the release of additional SOM. With heating at $90^{\circ} \mathrm{C}$, a high dosage of $\mathrm{NaOH}$ increased the cell wall destruction and the release of SOM (table 1). The untreated dried algae did not easily dissolve in water, and coagulated clumps were observed under the microscope (fig. 3).

The increase in bright green dots seen in the untreated dried algae samples compared to the other two untreated samples indicates cell destruction prior to pretreatment. Pretreated samples also had green patches, but the intensity was similar to untreated samples, and even less in one case (fig. 3c vs. fig. 3i). Drying helped to alter the cell structure and release SOM from the cell matrix, but it can decrease the fermentative potential of algae biomass (Mussgnug et al., 2010). Drying changes both the biological structure of the cells and the chemical merits of the organic compounds, and the latter determine the fermentative potential. If the change is detrimental, drying can limit the access of bacteria to organic compounds. 


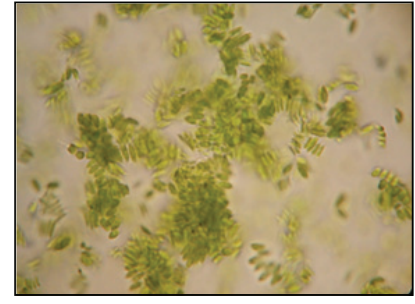

(a)

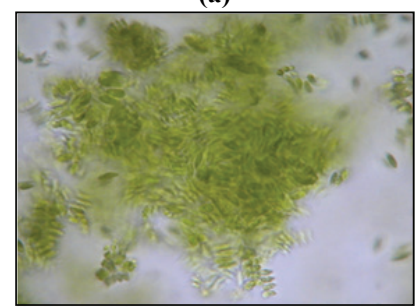

(d)

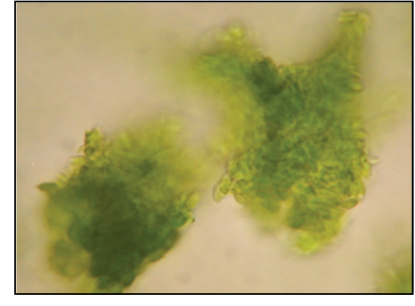

(g)

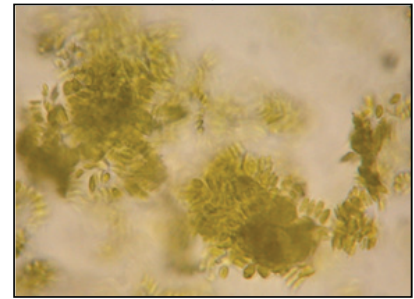

(j)

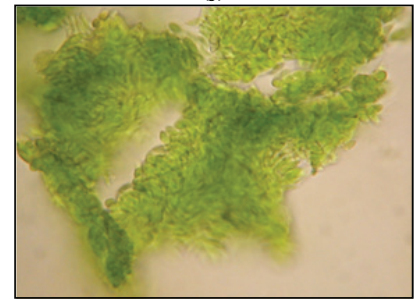

(m)

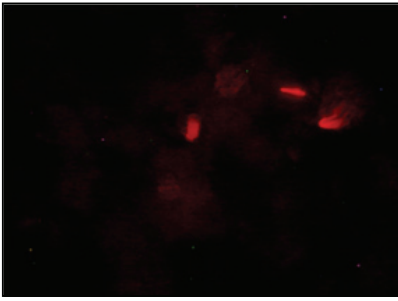

(b)

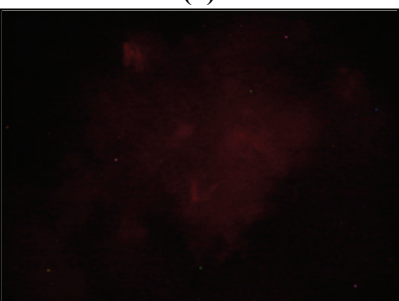

(e)

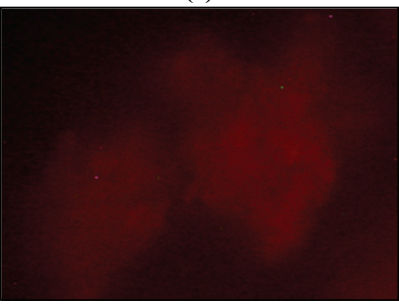

(h)

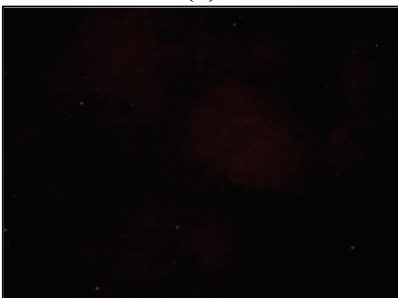

(k)

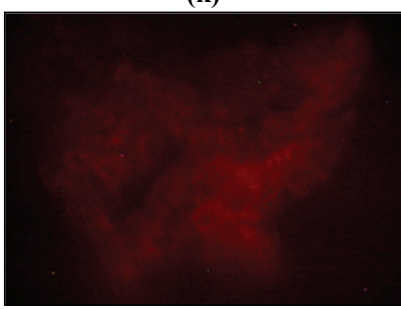

(n)

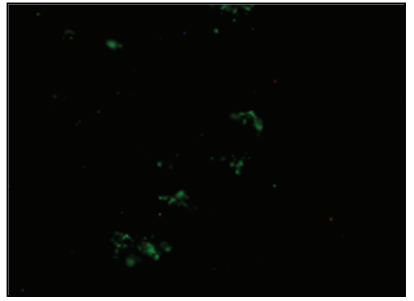

(c)

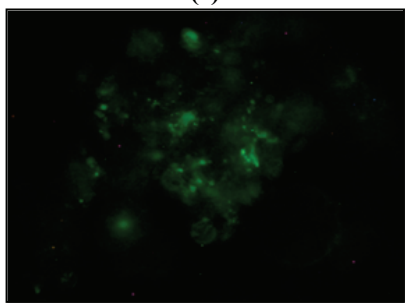

(f)

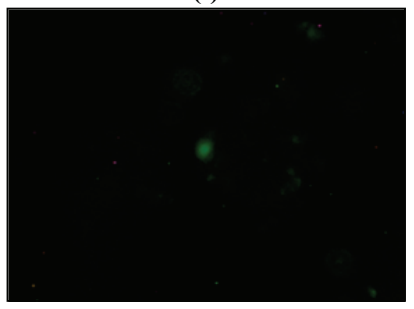

(i)

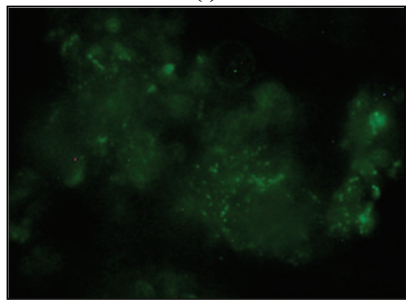

(I)

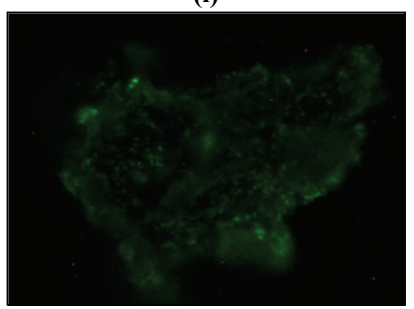

(o)

Figure 3. Microscopy images of dried algae: (left to right) light microscopy, red fluorescence microscopy representing live cells, and green fluorescence microscopy representing dead cells, (a-c) raw dried algae, (d-f) dried algae treated with $0 \% \mathrm{NaOH}$ at $50^{\circ} \mathrm{C}$ for $10 \mathrm{~min},(\mathrm{~g}-\mathrm{i})$ dried algae treated with $12 \% \mathrm{NaOH}$ at $50^{\circ} \mathrm{C}$ for $10 \mathrm{~min},(\mathrm{j}-\mathrm{l})$ dried algae treated with $0 \% \mathrm{NaOH}$ at $90^{\circ} \mathrm{C}$ for $10 \mathrm{~min}$, and $(\mathrm{m}-0)$ dried algae treated with $12 \% \mathrm{NaOH}$ at $90^{\circ} \mathrm{C}$ for $10 \mathrm{~min}$. 


\section{Conclusions}

Thermal pretreatment can effectively weaken algae cell walls and lead to the release of SOM from the cells with algae at a $10 \mathrm{~g} \mathrm{~L}^{-1}$ concentration. Different temperatures $\left(50^{\circ} \mathrm{C}\right.$ and $90^{\circ} \mathrm{C}$ ) showed more significant effects on flocculated algae and dried algae than on fresh algae. $\mathrm{NaOH}$ addition showed diminishing impacts on $\mathrm{SOM}$ release for fresh algae at $50^{\circ} \mathrm{C}$ but increased the amount of SOM released for fresh algae at $90^{\circ} \mathrm{C}$ and for the other two samples at $50^{\circ} \mathrm{C}$ and $90^{\circ} \mathrm{C}$. Duration $(10,30$, or $60 \mathrm{~min})$ failed to show a significant effect in most cases; however, with heating at $90^{\circ} \mathrm{C}$ and $12 \%$ of $\mathrm{NaOH}$, more $\mathrm{SOM}$ was leached out as the duration was extended. Ultimately, the selection of pretreatment parameters depends on the economics of the entire system. Fluorescence microscopy images confirmed that thermal chemical treatments disrupt cell walls; however, the images failed to show the magnitude of the disruption among various pretreatments.

\section{Acknowledgements}

The information reported in this paper (No. 14-05-075) is part of a project of the Kentucky Agricultural Experiment Station and is published with the approval of the Director. The authors would like to thank the Kentucky Department of Energy Development and Independence for funding and Dr. Gail Brion from ERTL at the University of Kentucky for fluorescent microscopy advice.

\section{References}

Appels, L., Degreve, J., Bruggen, B. V., Impe, J. V., \& Dewil, R. (2010). Influence of lowtemperature thermal pretreatment on sludge solubilisation, heavy metal release, and anaerobic digestion. Bioresource Tech., 101(15), 5743-5748.

Barjenbruch, M., \& Kopplow, O. (2003). Enzymatic, mechanical, and thermal pretreatment of surplus sludge. Adv. Environ. Res., 7(3), 715-720.

Bolto, B., \& Gregory, J. (2007). Organic polyelectrolytes in water treatment. Water Res., 41(11), 2301-2324.

Chen, P. H. (1987). Factors influencing methane fermentation of micro-algae. PhD diss. Berkeley, Cal.: University of California, Department of Civil Engineering.

Foree, E. G., \& McCarty, P. L. (1970). Anaerobic decomposition of algae. Environ. Sci. Tech., 4(10), 842-849.

Golueke, C. G., Oswald, W. J., \& Gotaas, H. B. (1957). Anaerobic digestion of algae. Appl. Microbiol., 4(1), 47-55.

Gonzalez-Fernandez, C., Sialve, B., Bernet, N., \& Steyer, J. P. (2011). Impact of microalgae characteristics on their conversion to biofuel: Part II. Focus on biomethane production. Biofuels Bioprod. Bioref., 6(2), 205-218.

Gonzalez-Fernandez, C., Sialve, B., Bernet, N., \& Steyer, J. P. (2012). Thermal pretreatment to improve methane production of Scenedesmus biomass. Biomass Bioenergy, 40, 105-111.

Halim, R., Harun, R., Danquah, M. K., \& Webley, P. A. (2012). Microalgal cell disruption for biofuel development. Appl. Energy, 91(1), 116-121.

Mendes-Pinto, M. M., Raposo, M. F., Bowen, J., Young, A. J., \& Morais, R. (2001). Evaluation of different cell disruption processes on encysted cells of Haematococcus pluvialis: Effects on astaxanthin recovery and implications for bio-availability. J. Appl. Phycol., 13(1), 19-24.

Miranda, J. R., Passarinho, P. C., \& Gouveia, L. (2012). Pretreatment optimization of Scenedesmus obliquus microalga for bioethanol production. Bioresource Tech., 104, 342-348.

Mussgnug, J. H., Klassen, V., Schluter, A., \& Kruse, O. (2010). Microalgae as substrates for fermentative biogas production in a combined biorefinery concept. J. Biotech., 150(1), 51-56. 
Ras, M., Lardon, L., Bruno, S., Bernet, N., \& Steyer, J. P. (2011). Experimental study on a coupled process of production and anaerobic digestion of Chlorella vulgaris. Bioresource Tech., 102(1), 200-206.

Sato, M., Murata, Y., Mizusawa, M., Iwahashi, H., \& Oka, S. (2004). A simple and rapid dualfluorescence viability assay for microalgae. Microbiol Cult. Coll., 20(2), 53-59. 